\title{
Poly-L-lysine Glycoconjugates Inhibit DC-SIGN-mediated Attachment of Pandemic Viruses
}

Jonathan Cramer, ${ }^{1), \sharp}$ Butrint Aliu,,${ }^{1),}$ Xiaohua Jiang, ${ }^{1)}$ Timothy Sharpe, ${ }^{2)}$ Lijuan Pang, ${ }^{1)}$ Adrian Hadorn, ${ }^{1)}$ Said Rabbani, ${ }^{1)}$ and Beat Ernst ${ }^{1) *}$

1) University of Basel, Department of Pharmaceutical Sciences, Pharmacenter of the University of Basel, Klingelbergstrasse 50, 4056, Basel, Switzerland

2) University of Basel, Biophysics Facility, Biocenter of the University of Basel, Klingelbergstrasse 70, 4056, Basel, Switzerland

* Corresponding author. Tel.: +41 $61207 \quad 15$ 51; Fax: +41 6120715 52; E-mail: beat.ernst@unibas.ch (B. Ernst)

$\$$ These authors contributed equally.

Keywords: C-type lectin receptors, COVID-19, SARS-CoV-2, Ebola, HIV, poly-L-lysine, multivalency, thermodynamics.

Abbreviations: CRD, carbohydrate recognition domain; ITC, isothermal titration calorimetry; $K_{\mathrm{D}}$, dissociation constant; DC-SIGN, dendritic cell-specific intercellular adhesion molecule 3 grabbing non-integrin; PLL, poly-L-lysine; DLS, dynamic light scattering; AUC, analytical ultracentrifugation; MeMan, methyl $\alpha$-D-mannoside. 


\section{Abstract (229 words)}

Envelope glycoproteins of many viruses are heavily glycosylated. Among other functions, virus glycans can mediate interactions with host receptors and contribute to internalization and virus dissemination. The C-type lectin receptor DC-SIGN, which is expressed by cells of the innate immune system, can act as an entry receptor for pathogens, including pandemic viruses such as SARS-CoV-2, ebola, and HIV. In the context of the recent SARS-CoV-2 pandemic, this mechanism has been linked to severe cases of COVID-19. Inhibition of the interaction between DC-SIGN and viral envelope glycoproteins has therefore the potential to generate broad spectrum antivirulent agents. Moreover, the important role of this mechanism in numerous viral infections, as well as an interaction partner conserved in the host genome highlight the potential of DC-SIGN-targeted therapeutics not only for the treatment of existing infections, but also for the rapid response to future pandemics with newly emerging virus serotypes. Here, we demonstrate that mannose-functionalized poly-L-lysine glycoconjugates efficiently inhibit the attachment of viral glycoproteins from SARS-CoV-2, ebola, and HIV to DC-SIGN-presenting cells with up to picomolar affinity. Treatment of susceptible cells leads to prolonged receptor internalization and statistically significant inhibition of virus binding for up to $6 \mathrm{~h}$. Furthermore, the polymers are fully biocompatible and readily cleared by the target cells. Finally, the thermodynamic analysis of these multivalent interactions revealed an entropy-driven affinity enhancement, opening promising perspectives for the future development of multivalent therapeutics. 


\section{Introduction}

Envelope glycoproteins of a variety of viruses are densely covered with host-derived carbohydrates. These glycan structures shield viruses from antibody-mediated immune responses, enabling the attachment to the host's lectins ${ }^{[1,2]}$ One of these lectins is the C-type lectin receptor (CLR) DC-SIGN (dendritic cell-specific intercellular adhesion molecule 3 grabbing non-integrin), a surface receptor expressed by innate immune cells. It has been demonstrated that DC-SIGN acts as an entry receptor for pathogens and plays a detrimental role in the pathology of many viral infections by promoting virus dissemination and immune evasion. ${ }^{[1-4]}$ High-mannose glycan epitopes on envelope glycoproteins of epidemic and pandemic viruses such as HIV, ${ }^{[5]}$ ebola, ${ }^{[6,7]}$ influenza $A,{ }^{[8]}$ hepatitis $\mathrm{C},{ }^{[9]} \mathrm{SARS},{ }^{[10]} \mathrm{zika}^{[11]}$ dengue, ${ }^{[12]}$ and others, ${ }^{[1]}$ have been shown to enable DC-SIGN mediated attachment and internalization, either for $c i s$-infection of myeloid cells or for trans-infection of other cell types. $^{[4,10,13,14]}$

In the context of the ongoing SARS-CoV-2 pandemic, increasing evidence points to a possible involvement of DC-SIGN in virus attachment to innate immune cells. ${ }^{[15]}$ The SARS-CoV-2 spike protein is heavily glycosylated with high mannose and complex N-glycans, which potentially could serve the attachment to host lectins. ${ }^{[16]}$ In fact, several groups have demonstrated that these glycans are indeed recognized with picomolar affinity by various CLRs such as DC-SIGN and the closely related DC-SIGNR. ${ }^{[17-21]}$ The interaction of the viral spike glycoprotein leads to internalization in DC-SIGN-presenting cells, strongly implicating DCSIGN as an ACE2-independent entry receptor for SARS-CoV-2. Infection of innate immune cells by this mechanism could contribute to the exaggerated immune response in severe COVID-19. This is consistent with the fact that DC-SIGN expression levels were increased in severe COVID-19 patients with elevated amounts of proinflammatory monocyte-derived macrophages, inflammatory cytokines and chemokines. ${ }^{[17]}$ Another recent study confirmed DC- 
SIGN-mediated internalization of SARS-CoV-2 pseudovirions into monocyte-derived dendritic cells, albeit without cis-infection of the cells. ${ }^{[22]}$ However, dendritic cells pre-treated with SARS-CoV-2 pseudovirions efficiently infected ACE2+ Vero cells in a trans-infection assay, thereby indicating a deciding role of DC-SIGN for virus dissemination from the lung to other tissues. Importantly, trans-infection could be inhibited with a known DC-SIGN ligand. Differences in SARS-CoV-2 virulence due to mutation in the viral spike glycoprotein, such as the prominent D614G mutation, have been attributed to potential variations in glycosylation, resulting in differences in the interaction with DC-SIGN and DC-SIGNR. ${ }^{[15]}$ Furthermore, a recent study concluded that genetic variants in the $A B O$ gene locus correlate with DC-SIGN expression levels and that increased DC-SIGN expression represents a genetic risk factor for severe COVID-19, indicating a central role of the innate immune system in this disease. ${ }^{[23]}$

With this background, inhibition of DC-SIGN-mediated attachment of viral particles to innate immune cells represents a promising strategy for the development of antiviral drugs. ${ }^{[24-26]}$ In the past, this strategy has been investigated for the treatment of HIV, ${ }^{[20]}$ ebola, ${ }^{[27]} \mathrm{zika}^{[28]}$ and dengue infections. ${ }^{[28]}$ In view of the recent emergence of the SARS-CoV-2 pandemic, DCSIGN-targeted antivirals could represent a promising host-directed treatment option for COVID-19. Importantly, metabolic pathways responsible for glycosylation of viral proteins, as well as the targeted glycan receptors are evolutionarily conserved in the host genome. It can therefore be assumed, that the pharmacological interference in this mechanism with antiviral therapeutics is insensitive to viral resistance mutations and additionally provides the possibility for an early containment of infections from newly emerging virus strains with pandemic potential. ${ }^{[29]}$

Multivalent presentations of viral glycans employing mannose or fucose epitopes have been explored as potential inhibitors of DC-SIGN-mediated virus attachment. Multivalent carbohydrate-lectin interactions often proceed via statistical rebinding, or a bind-and-jump 
mechanism. ${ }^{[30,31]}$ Accordingly, carbohydrate epitopes on a multivalent scaffold migrate along a surface presenting the carbohydrate recognition domain (CRD) of the lectin, while undergoing numerous association and dissociation events. Even though the individual monovalent interactions of the epitopes are weak, the macroscopic apparent binding affinity, i.e. the probability of the lectin being bound to any carbohydrate ligand on the surface, is much higher. This mechanism leads to an increase in apparent binding affinity of protein-carbohydrate interactions of up to a factor of $10^{6} .^{[32,33]}$ In this context, functionalized polymeric supports, ${ }^{[34]}$ peptides, ${ }^{[35]}$ dendrimers, ${ }^{[36]}$ nanoparticles, ${ }^{[37]}$ fullerenes, ${ }^{[28]}$ carbon nanotubes, ${ }^{[27]}$ and thiacalixarenes ${ }^{[38]}$ have been studied. However, a severe drawback of some of these nonbiodegradable multivalent scaffolds is their potential accumulation and associated toxicity, especially when prolonged pulmonary applications are considered. ${ }^{[39,40]}$

Here, we report the synthesis and biological evaluation of mannosylated poly-L-lysine glycoconjugates (Man-PLL) 1a-d as multivalent ligands for DC-SIGN. By relying on poly-Llysine as a polymeric scaffold we resort to a broadly available system that is easily modified, non-immunogenic, biodegradable, and extensively studied for biological applications. ${ }^{[41-44]} \mathrm{We}$ demonstrate that glycopolymers 1a-d efficiently block the interaction of DC-SIGN expressing $\left(\right.$ DC-SIGN $\left.{ }^{+}\right)$cells with viral glycoproteins from HIV, Ebola, and SARS-CoV-2. In addition, we show that the glycopolymers are readily cleared by the target cells and, thus, show great potential for compatibility with prolonged pulmonary application in a therapeutic setting. In addition, the binding affinity, thermodynamics, and stoichiometry of the multivalent interactions between glycopolymers 1a-d and recombinant DC-SIGN are characterized by isothermal titration calorimetry (ITC). 


\section{Results and Discussion}

Man-PLL 1a-d were synthesized from commercially available poly-L-lysine hydrobromide (2) by chloroacetylation $(\rightarrow \mathbf{3})$ followed by chloride substitution with various amounts of the thiol functionalized mannoside (4) (Scheme 1). ${ }^{[45]}$ The unreacted chloroacetamides were then reacted with an excess of thioglycerol. This operationally simple synthetic sequence yielded the water-soluble glycopolymers 1a-d with varying carbohydrate loadings. It is important to note that commercially available poly-L-lysine polymers are polydisperse systems with a degree of polymerization distributed around a statistical mean. This affects all calculations of concentration, loading, and affinity, which represent estimates based on the assumption of an ideal, monodisperse polymer.

\section{Synthesis of Man-PLL 1a-d}

Mannose building block 4 was obtained in an overall yield of $25 \%$ in a short synthetic sequence starting from D-mannose pentaacetate (5). $\alpha$-Selective glycosylation with 3-chlorpropan-1-ol yielded mannoside $\mathbf{6}$. Azide substitution of chloride $(\rightarrow 7)$, Zemplén deacetylation $(\rightarrow \mathbf{8})$ and catalytic hydrogenation gave the unprotected amine 9. Finally, reaction with $\gamma$ thiobutyrolactone gave building block $\mathbf{4}$ in good yield.

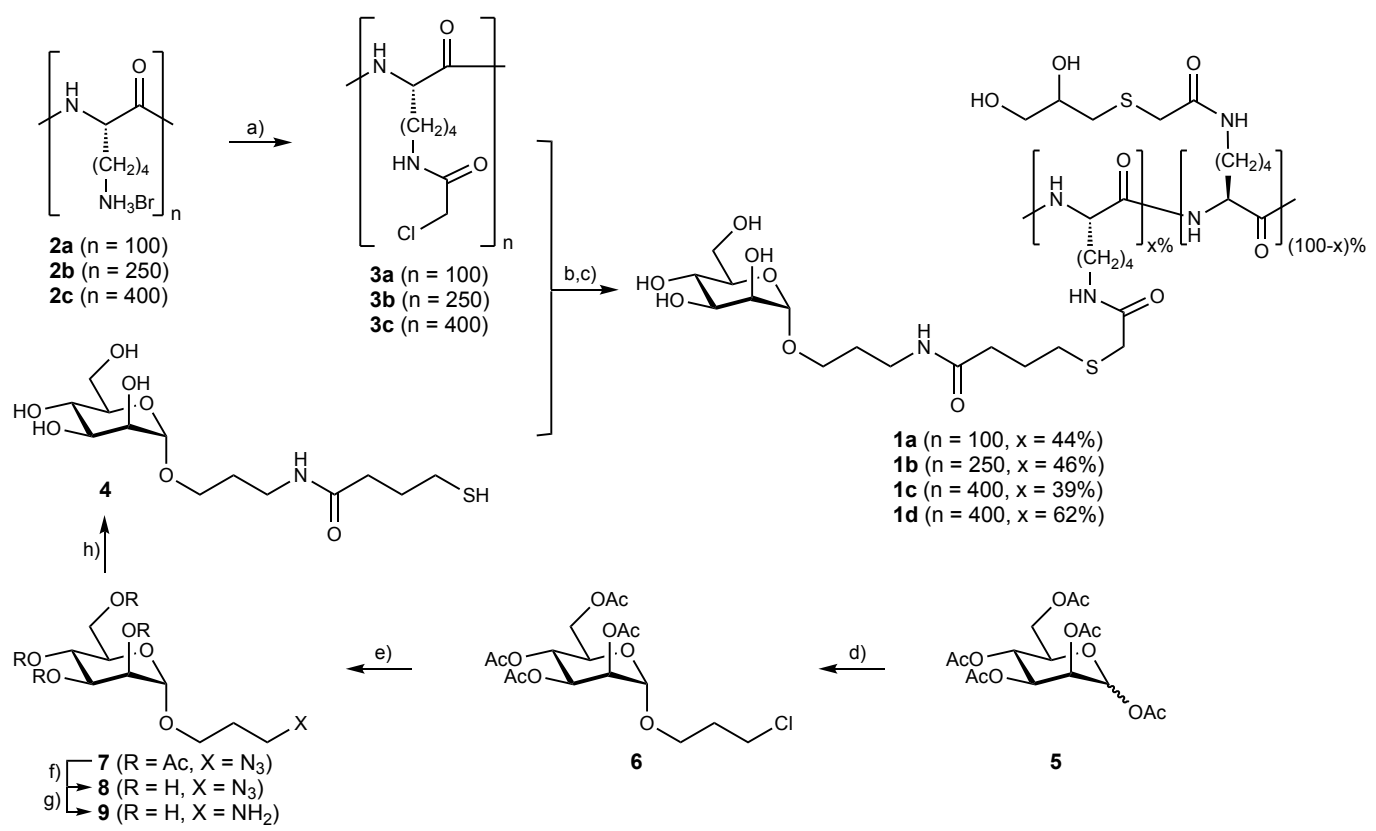


Scheme 1. Synthesis of the mannosylated poly-L-lysine glycoconjugates 1a-d; (a) 2,6-lutidine, chloroacetic anhydride, $4^{\circ} \mathrm{C}, 16 \mathrm{~h}(3 \mathbf{a}(92 \%), 3 \mathbf{b}(62 \%), 3 \mathbf{c}(96 \%))$; b) 1,8-diazabicyclo(5.4.0)undec-7-ene/DMF, building block 4, without purification c) thioglycerol, $\mathrm{Et}_{3} \mathrm{~N}$, shaken overnight: 1a (45\%, loading 44\%); 1b (64\%, loading 46\%); 1c $(68 \%$, loading $39 \%)$; 1d (51\%, loading 62\%). d) 3-chloro-1-propanol, $\mathrm{BF}_{3} \bullet \mathrm{Et}_{2} \mathrm{O} / \mathrm{CH}_{2} \mathrm{Cl}_{2}$, rt, overnight, (65\%); (e) $\mathrm{NaN}_{3} / \mathrm{DMF}, 60^{\circ} \mathrm{C}, 2 \mathrm{~h},(95 \%)$; (g) $\mathrm{MeONa} / \mathrm{MeOH}, \mathrm{rt}$, overnight, $(83 \%)$; (h) $\mathrm{Pd}(\mathrm{OH})_{2} / \mathrm{C}$ in $\mathrm{MeOH}, \mathrm{H}_{2},(84 \%)$; (i) $\gamma$-thiobutyrolactone, $\mathrm{MeOH} / \mathrm{Et}_{3} \mathrm{~N}, \mathrm{rt}$, overnight, $(68 \%)$.

According to this strategy, a series of Man-PLL of different lengths and loadings were prepared (Table 1).

Table 1. Poly-L-lysine glycopolymers prepared for the study of DC-SIGN binding.

\begin{tabular}{|c|c|c|c|c|}
\hline Compound & $\begin{array}{c}\text { Degree of } \\
\text { polymerization; } \\
\text { lysine residues n }\end{array}$ & $\begin{array}{c}\text { Absolute number of } \\
\text { mannose residues by } \\
\text { NMR }\end{array}$ & $\begin{array}{c}\text { Carbohydrate } \\
\text { loading } x\end{array}$ & $\begin{array}{c}\text { Average molecular } \\
\text { weight [kDa] }\end{array}$ \\
\hline Man-PLL100 (1a) & 100 & 44 & $44 \%$ & 37.8 \\
\hline Man-PLL250 (1b) & 250 & 115 & $46 \%$ & 95.0 \\
\hline Man-PLL400 (1c) & 400 & 156 & $39 \%$ & 146.6 \\
\hline Man-PLL400 (1d) & 400 & 248 & $62 \%$ & 167.9 \\
\hline
\end{tabular}

\section{Biophysical characterization of Man-PLL polymers}

The size distribution and the shape of Man-PLL 1a-d in solution were elucidated by dynamic light scattering (DLS) experiments and analytical ultracentrifugation (AUC). As shown in Table 2, Figure 1A, the measured hydrodynamic diameters $\left(D_{h}\right)$ of 1a-d reflect the degree of polymerization. $A D_{h}$ of $9.2 \mathrm{~nm}$ was found for Man-PLL $L_{100}(\mathbf{1 a})$, which is roughly doubled for the 250-mer $\mathbf{1 b}(19.8 \mathrm{~nm})$ and tripled for the larger 400-mers $\mathbf{1 c}$ and $\mathbf{1 d}(30 \mathrm{~nm})$. The polydispersity indices $(\mathrm{Ð})$ fall in a range of 0.3 to 0.4 , indicating the presence of multiple species in the polymer samples, as expected for the polydisperse PLL scaffolds. Next, diffusiondeconvoluted differential sedimentation coefficient distributions (c(s) distributions) were determined by analytical ultracentrifugation (AUC) and signal-weight average sedimentation coefficients (S) were calculated for each polymer (Table 2, Figure 1B). Values of frictional 
ratio $\left(f / f_{0}\right)$ fitted from AUC data provide information about the shape of macromolecules in solution. Whereas a value for $f / f_{0}$ of 1 corresponds to a spherical shape, values $>2.0$ indicate a highly extended conformation. Based on sedimentation velocity data, a narrow distribution with an average sedimentation coefficient of $2.21 \mathrm{~S}$ was obtained for Man-PLL100 (1a). These parameters were used to calculate a molecular mass estimate of $39.6 \mathrm{kDa}$, which correlates well with the theoretical value of $37.8 \mathrm{kDa}$. For Man-PLL $100(\mathbf{1 a})$, the recorded frictional ratio of 1.4 suggests a globular shape, comparable to a folded protein. The hydrodynamic radius $\left(D_{h}\right)$ calculated from the average sedimentation coefficient is $6.6 \mathrm{~nm}$. Experimental data for the larger glycopolymers 1b-d showed more complex distributions, revealing the presence of multiple species with sedimentation coefficients between 2 and $15 \mathrm{~S}$. Molecular mass estimations for these species correlate not only to polymer monomers, but also dimers and higher order aggregates (Figure S10). The calculated $\mathrm{D}_{\mathrm{h}}$ from the average sedimentation coefficients are between $20.9 \mathrm{~nm}$ and $24.3 \mathrm{~nm}$, a sign for larger particle sizes for the longer polymers compared with 1a, which corroborates DLS data. Finally, based on the average frictional ratios with values between 2.37 and 2.52, a highly extended conformation of the polymers can be assumed.

Table 2. Biophysical characterization of Man-PLL 1a-d by DLS and AUC.

\begin{tabular}{|c|c|c|c|c|c|}
\hline \multirow{2}{*}{ Man-PLL } & \multicolumn{2}{|c|}{ DLS } & \multicolumn{3}{c|}{ AUC } \\
\cline { 2 - 6 } & $\mathrm{D}_{\mathrm{h}[\mathrm{nm}]^{a, b}}$ & $\mathrm{D}$ & Sedimentation coefficient $[\mathrm{S}]^{c}$ & $f / f_{0}$ & $\mathrm{D}_{\mathrm{h}}[\mathrm{nm}]$ \\
\hline $\mathbf{1 a}$ & $9.2 \pm 0.4$ & $0.4 \pm 0.01$ & 2.21 & 1.41 & 6.6 \\
\hline 1b & $19.8 \pm 0.3$ & $0.4 \pm 0.05$ & 4.04 & 2.50 & 20.9 \\
\hline 1c & $32.0 \pm 0.4$ & $0.3 \pm 0.02$ & 5.08 & 2.37 & 21.5 \\
\hline 1d & $27.2 \pm 0.7$ & $0.4 \pm 0.02$ & 5.24 & 2.52 & 24.3 \\
\hline
\end{tabular}

${ }^{a}$ Z-Average values are reported as hydrodynamic radii. ${ }^{b}$ The standard deviation from three independent experiments is given as an estimation of experimental error. ${ }^{c}$ Signal weighted average over the range $1-20 \mathrm{~S}$. $\mathrm{D}_{\mathrm{h}}$, hydrodynamic diameter; $Đ$, polydispersity index; $f / f_{0}$, frictional ratio. 

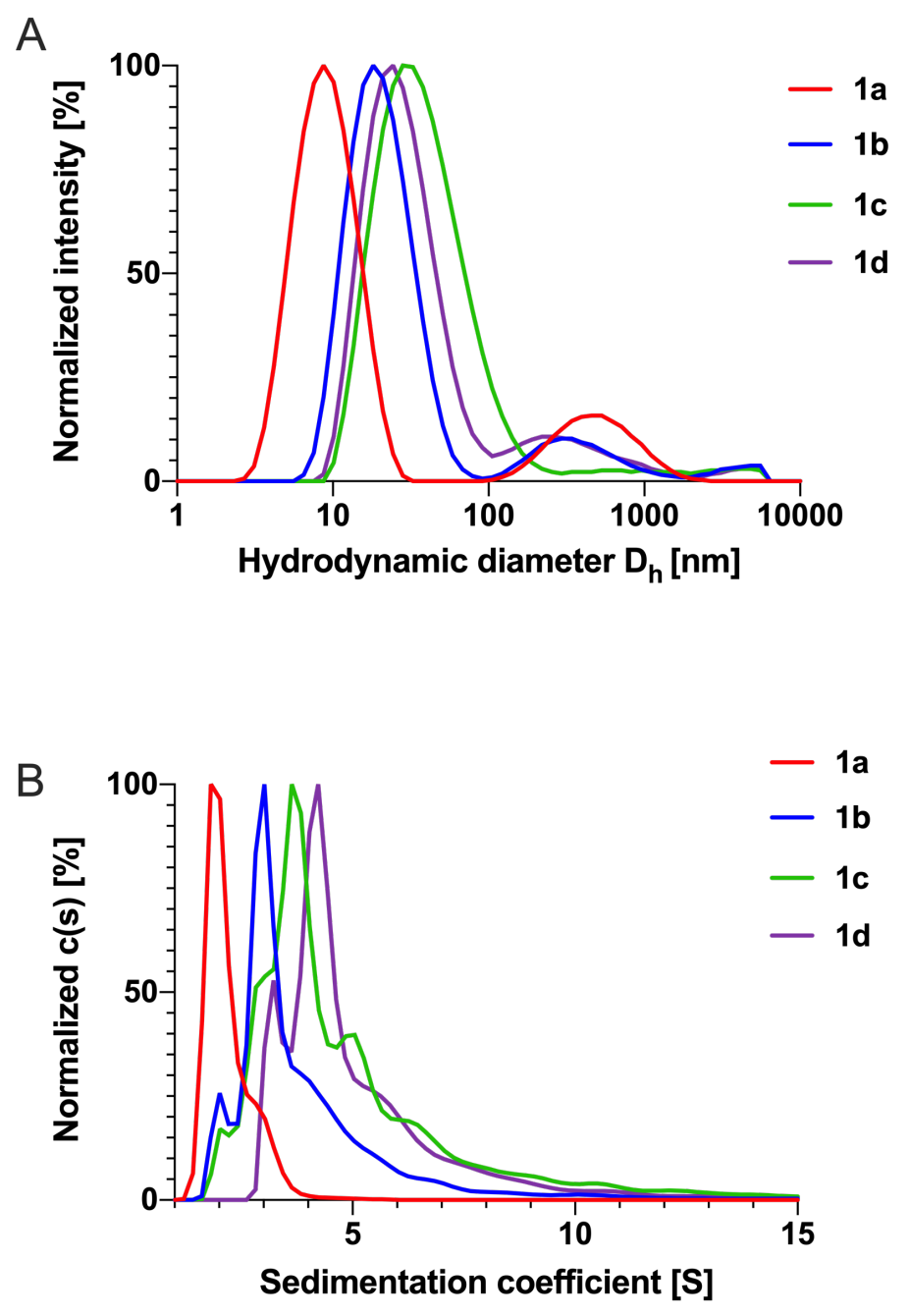

Figure 1. A) Normalized scattering intensity distribution for Man-PLL 1a-d as determined by DLS. B) Normalized diffusion-deconvoluted differential sedimentation coefficient distributions (c(s) distributions) for 1a-d determined by sedimentation velocity AUC experiments. The magnitude of $\mathrm{c}(\mathrm{s})$ at a given $\mathrm{S}$ value gives the proportion of the total material in that sample having that $\mathrm{S}$ value.

\section{Competitive inhibition of viral glycoprotein binding to $\mathrm{DC}^{-S I G N}{ }^{+}$cells}

The potential of Man-PLL 1a-d to inhibit the attachment of viral glycoproteins from SARSCoV-2 (spike glycoprotein S1 subunit), ebola (EBOV glycoprotein), or HIV (gp120 envelope glycoprotein) to DC-SIGN ${ }^{+}$B-THP-1 cells was investigated using a flow-cytometric assay (Figure 2). DC-SIGN ${ }^{+}$cells or isotype controls were incubated with the viral glycoproteins labeled with the cyanine dye Cy5 in the presence of either logarithmic dilutions of 
glycopolymers 1a-d or buffer, as described in the experimental section. The amount of fluorescently labeled glycoprotein bound to the cell surface was determined by mean fluorescence intensity and the resulting competition curves were fitted to a four parameter Hill model to determine $\mathrm{IC}_{50}$ values. The shortest Man-PLL 100 (1a) showed an $\mathrm{IC}_{50}$ value of $43 \mathrm{nM}$ for SARS-CoV-2 spike S1 and $36 \mathrm{nM}$ for EBOV glycoprotein. In contrast, the affinities for the intermediate length Man-PLL250 (1b) are in the subnanomolar range (789 pM and $637 \mathrm{pM})$, which corresponds to an affinity gain of approximately a factor of 50. However, further elongation of the polymer backbone $(\mathbf{1 b} \rightarrow \mathbf{1 c})$ and increase in mannose loading $(\mathbf{1 c} \rightarrow \mathbf{1 d})$ resulted only in a moderate increase of the binding affinities by a factor of two. With $\mathrm{IC}_{50}$ values around 200 pM, $1 d$ is a highly potent inhibitor of the interaction between SARS-CoV-2 spike S1 and EBOV glycoprotein with DC-SIGN. Compared with the monovalent epitope methyl $\alpha-$ D-mannoside (MeMan, $\mathrm{IC}_{50}=6.5 \mathrm{mM}$ ), the multivalent affinity enhancement is in the order of $10^{7}$. For HIV gp120, an identical trend in affinity was observed, however with absolute $\mathrm{IC}_{50}$ values being worse by a factor of five. For the most potent Man-PLL400 (1d), this resulted in an $\mathrm{IC}_{50}$ value of $1.0 \mathrm{nM}$. The less potent inhibition of the gp120/DC-SIGN interaction is probably linked to a higher binding affinity of the heavily glycosylated gp120 compared with the other glycoproteins. $^{[16,46]}$ 
SARS-CoV-2 Spike S1

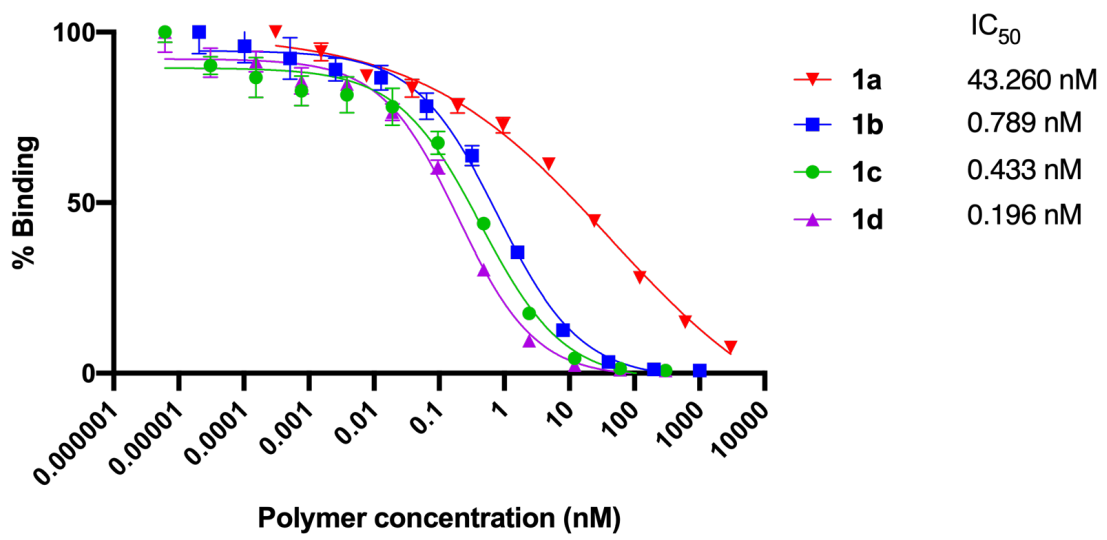

EBOV-gp

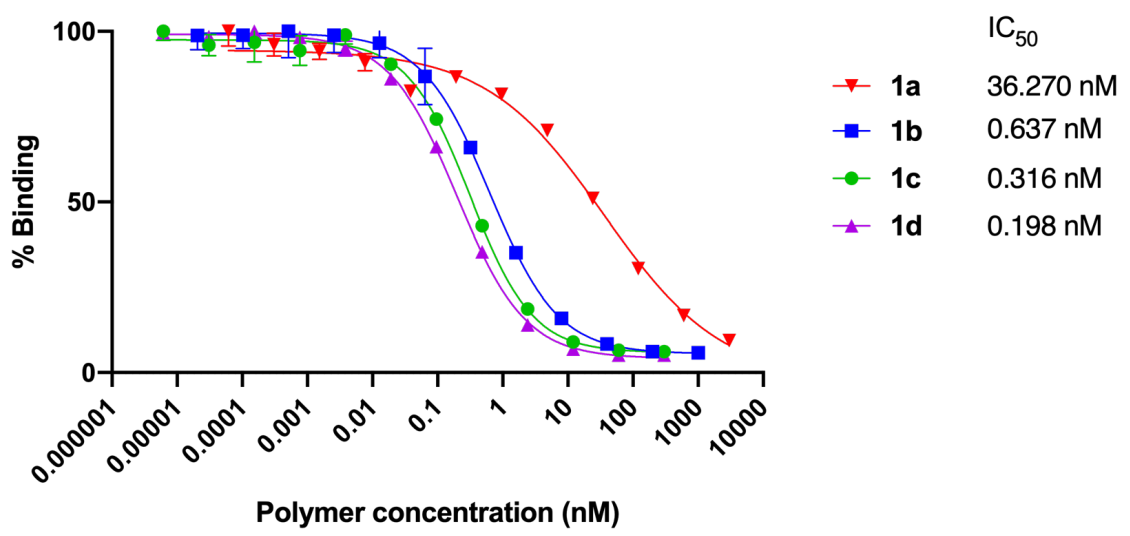

HIV gp120

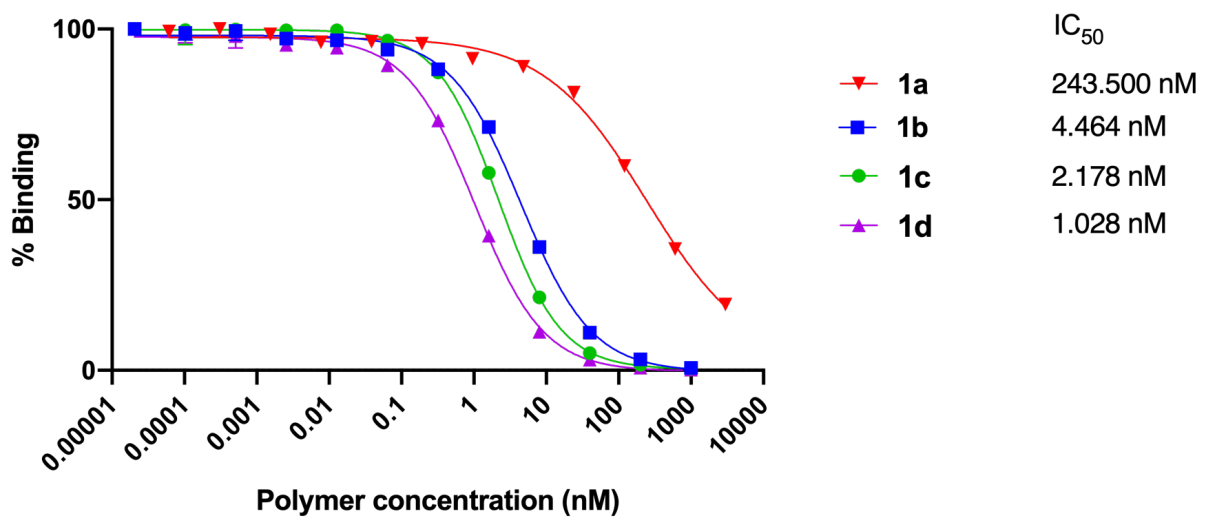

Figure 2. Inhibition of viral glycoprotein attachment to DC-SIGN ${ }^{+}$B-THP-1 cells. Cells were incubated with Man-PLL 1a-d in the presence of Cy5 labeled SARS-CoV-2 spike glycoprotein S1 subunit (10 nM), ebola 
glycoprotein (50 nM), or HIV gp120 (10 nM). Mean fluorescence intensity determined by flow cytometry was normalized before global fitting to a four parameter Hill model. Error bars represent the standard deviation from three independent experiments.

Intriguingly, the observed trend in affinity in the cellular assay correlates well with the solution properties of the Man-PLL glycopolymers determined by DLS and AUC (Table 2, Figure 1). The differences in size and shape are reflected in a significantly higher binding affinity (approximately a factor of 50) of elongated polymers $\mathbf{1 b - d}$ in cellular assays compared with the globular 1a. By comparison, between 1b-d, the variations in the degree of polymerization (1) $\rightarrow \mathbf{1 c})$ and carbohydrate loading $(\mathbf{1 c} \rightarrow \mathbf{1 d})$ influences affinity only by a factor of two. The observation that the elongated glycopolymers $\mathbf{1 b}$-d show much higher affinity compared to the globular $\mathbf{1 a}$ is probably related to the fact that DC-SIGN has evolved to capture large pathogens, such as viruses (ca. 20-500 nm) or bacteria (1-2 $\mu \mathrm{m}$ ), and not soluble glycoproteins. A similar influence of particle size of antigen formulations on DC-SIGN affinity and antigen uptake has been reported by the van Kooyk group. ${ }^{[47]}$

Prolonged incubation of DC-SIGN ${ }^{+}$B-THP-1 cells with the most potent inhibitor $1 \mathbf{d}$ effectively blocked the DC-SIGN receptors, making them unavailable for binding to SARS-CoV-2 spike $\mathrm{S} 1$ for up to $6 \mathrm{~h}$ (Figure 3A). An effect could still be observed after only a 30 min exposure of the cells (Figure 3B). Whereas inhibition was incomplete compared to a prolonged exposure to Man-PLL $_{400}(\mathbf{1 d})$, the binding of SARS-CoV-2 spike S1 was still significantly decreased for up to $6 \mathrm{~h}$ post incubation.

A

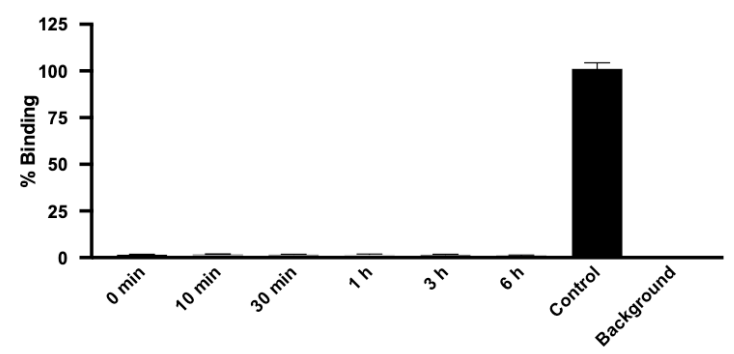

B

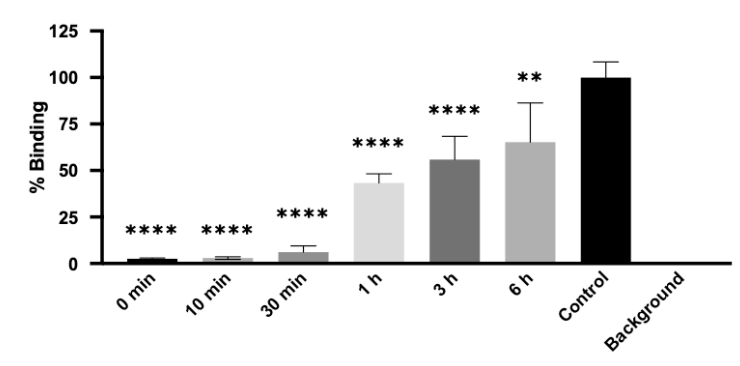


Figure 3. Inhibition of the DC-SIGN receptor on B-THP-1 cells by 1d. A) Incubation of the cells with $100 \mathrm{nM} 1 \mathbf{d}$ lead to a sustained blocking of the DC-SIGN receptor for at least 6 hours, thereby successfully preventing the binding of Cy5 labeled SARS-CoV-2 spike glycoprotein S1 subunit (10 nM). B) Pre-incubation of the cells with $100 \mathrm{nM} 1 \mathrm{1d}$ for $30 \mathrm{~min}$ showed a time dependent recovery of the receptor with a significantly decreased binding availability for at least $6 \mathrm{~h}$. Results are shown as mean with standard deviation from three independent experiments (one-way ANOVA, $* \mathrm{P} \leq 0.05, * * \mathrm{P} \leq 0.01, * * * \mathrm{P} \leq 0.001, * * * * \mathrm{P} \leq 0.0001)$.

\section{Uptake of Man-PLL 1a-d into target cells}

To study endocytosis into acidic cell compartments by flow cytometry and fluorescence microscopy, Man-PLL ${ }_{400}$ was labeled with the $\mathrm{pH}$-sensitive fluorescent dye rhodamine $6 \mathrm{G}$ (Man loading: 47\% by NMR, for synthesis of 10, see Supporting Information). As negative control, the fluorescently labeled PLL $_{400} \mathbf{1 1}$ containing no mannose modification was used (for synthesis of 11, see Supporting Information). Both polymers were incubated with DC-SIGN ${ }^{+}$ B-THP-1 cells and control B-THP-1 cells. Fluorescently labeled Man-PLL 40010 was internalized highly specifically by DC-SIGN expressing B-THP-1 cells (Figure 4A) and the fluorescent signal increased over $6 \mathrm{~h}$ and diminished after $24 \mathrm{~h}$ hours, highlighting a complete degradation of the compound as previously described by Hoppe and Lee. ${ }^{[4]}$ In contrast, no uptake was observed in control B-THP-1 cells and only minor uptake of non-mannosylated control PLL 40011 into both cell types was observed (Figure 4)

These observations further elucidate the mode of action of the Man-PLL. Multivalent binding to DC-SIGN on the cell surface causes effective inhibition of the binding of viral glycoproteins. Additionally, the compound is readily endocytosed via DC-SIGN. As a result, the availability of DC-SIGN on the cell surface is substantially reduced, and the glycopolymers are efficiently metabolized (Figure 4B). 
A

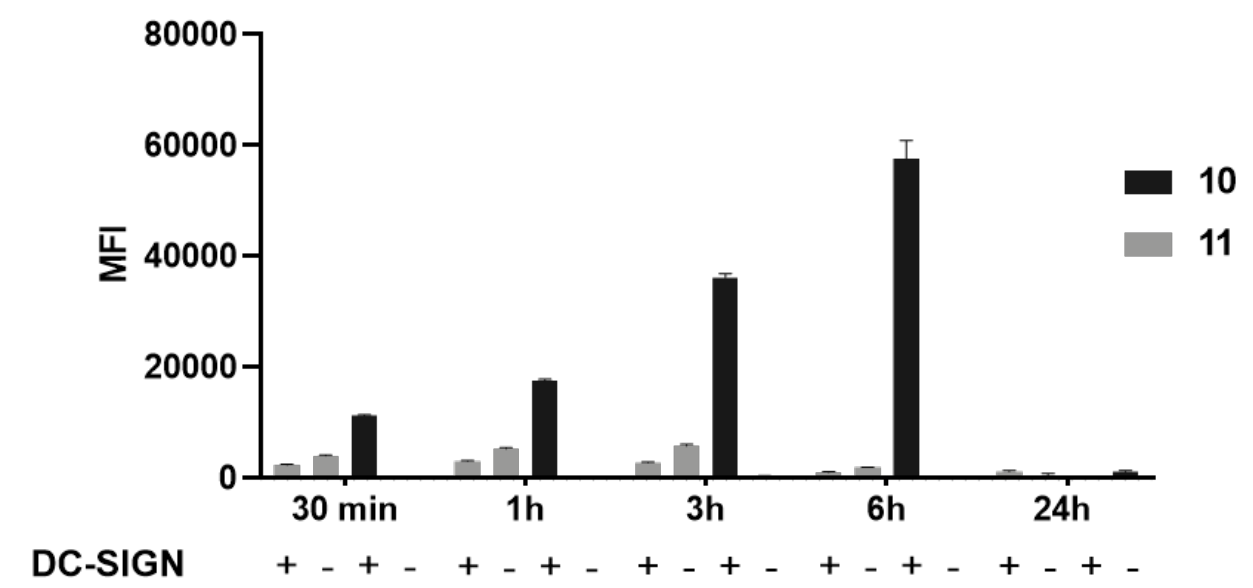

B
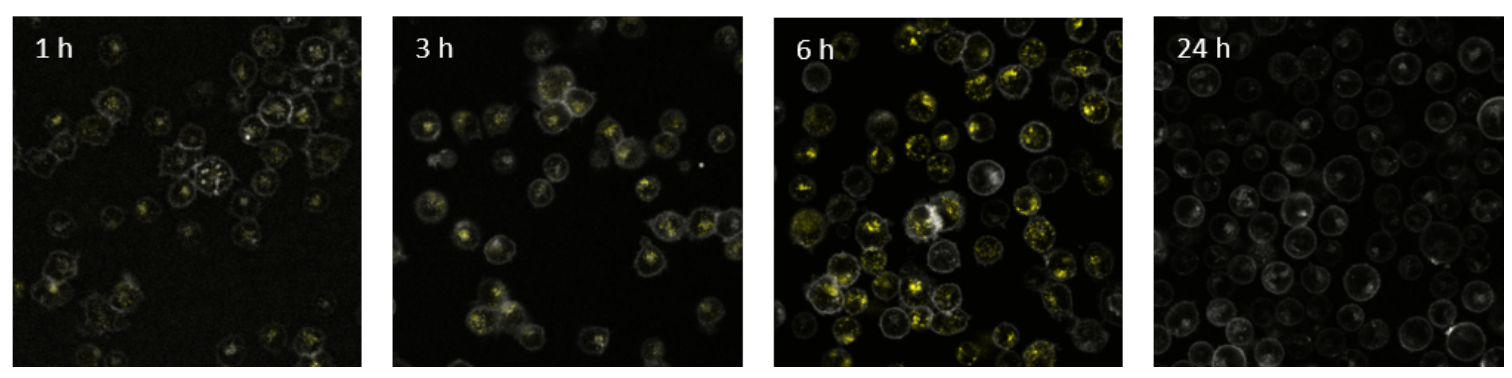

Figure 4. DC-SIGN mediated uptake and degradation of fluorescently labeled Man-PLL 400 10 into B-THP-1 cells. DC-SIGN ${ }^{+}$B-THP-1 cells and control B-THP-1 cells were incubated with $100 \mathrm{nM}$ rhodamine $6 \mathrm{G}$ labeled ManPLL $_{400} 10$ or $100 \mathrm{nM}$ rhodamine 6G labeled PLL 400 11. A) The internalization was quantified by measuring the $\mathrm{pH}$-dependent mean fluorescence intensity with flow cytometry, showing the highly specific and time-dependent uptake of $\mathbf{1 0}$ by DC-SIGN ${ }^{+}$B-THP-1 cells (+) in comparison to control B-THP-1 cells (-) and control $\mathbf{1 1}$. Furthermore, after increasing fluorescence intensity over time, the signal disappeared after $24 \mathrm{~h}$, highlighting the targeted uptake and degradation. B) Representative images recorded with confocal microscopy reveal the time dependent uptake of $\mathbf{1 0}$ in acidic cell compartments of DC-SIGN ${ }^{+}$B-THP-1 cells and the effective degradation after $24 \mathrm{~h}$. Error bars represent the standard deviation from three independent experiments.

\section{Analysis of binding thermodynamics}

Whereas the above discussed competitive cell assay yields data about the potency of Man-PLL 1a-d, it does not provide detailed information about the specifics of the interaction on a molecular level. To gain more insight into molecular details of the Man-PLL/DC-SIGN 
interaction, the affinity, stoichiometry $(n)$, and thermodynamics of binding were determined by isothermal titration calorimetry (ITC) with the tetrameric recombinant extracellular domain of DC-SIGN (ECD, 375 amino acids). It is important to note that this biophysical assay operates under a fundamentally different principle compared to the cellular assay. The ITC experiment records the interaction of soluble tetrameric DC-SIGN molecules with the polymeric ligands, whereas in the cellular assay the interaction of two mutually compatible multivalent surfaces is studied. In contrast to the affinity data determined in the cellular assay, a linear increase of the binding affinity $K_{\mathrm{D}}$ (Figure 5) from 1a to 1d was observed in the ITC experiment. Compared to the monovalent ligand MeMan $\left(K_{\mathrm{D}}=3.2 \mathrm{mM}\right)$, the multivalent presentation enhances affinity by a factor of $2.6 \times 10^{3}$ for $1 \mathbf{a}$ and up to a factor of $13.5 \times 10^{3}$ for $\mathbf{1 d}$. This difference in the multivalent affinity enhancement between the cellular assay and the interaction of the glycopolymers with soluble lectin receptors (see Figure 2 and 5) can be attributed to the multivalent presentation of receptor molecules on the cell surface, which effectively potentiates the affinity enhancement from statistical rebinding by providing a much higher effective local concentration of receptors. While an equivalent affinity trend is observable in ITC experiments and the cellular assay, the difference between $\mathbf{1 a}$ and $\mathbf{1 b - 1 d}$ is much less pronounced in the ITC assay with soluble protein (factor of 3-5) compared with the cellular assay (factor of 50-200), indicating that Man-PLL shape and hydrodynamic diameter are better predictors for activity in a cellular system than binding affinity from ITC. In summary, this observation indicates that, on the cellular level, the interaction with DC-SIGN is controlled by effects that are not fully reproduced in a biophysical assay employing soluble recombinant protein.

The affinity trend in ITC measurements roughly follows the increase of the functional valency $N$, which is defined as the inverse of the experimentally determined fitting parameter $n(N=$ $1 / n)$ and corresponds to the number of interacting mannose epitopes on the glycopolymer. $N$ can be related to the total number $N_{\max }$ of mannose epitopes on the respective polymer. With 
an $N / N_{\max }$ of $109 \%$ and $93 \%$, the mannose epitopes of the shorter polymers $\mathbf{1 a}$ and $\mathbf{1 b}$ appear to be fully saturated, whereas only a fraction of available mannose residues in the longer polymers $1 \mathrm{c}$ and $\mathbf{1 d}$ bind to the receptor (with $N / N_{\max } 58 \%$ and $48 \%$, respectively). Taking into account the broad distribution of high MW species in AUC experiments (Figure 1A), it is likely that self-aggregation reduces the accessibility of sugar residues on the Man-PLL400 $1 \mathbf{c}$ and $\mathbf{1 d}$. The reduction of the active mannose concentration in the samples is reflected in the ITC fitting parameter $n$, which leads to a reduced value of $N / N_{\max }$. A similar reduction of efficiency related to higher carbohydrate loading, not polymer length as in this case, has been observed for other glycopolymers. ${ }^{[48-51]}$ Interestingly, aggregation does not reduce the availability of mannose epitopes on the polymer surface for $\mathbf{1 b}$. The intermediate length polymer is, thus, most efficient in terms of affinity gain per carbohydrate epitope on the polymer.

$\begin{array}{ccccc} & \mathbf{1 a} & \mathbf{1 b} & \mathbf{1 C} & \mathbf{1 d} \\ K_{\mathrm{D}}[\mathrm{nM}] & 1227(1034-1474) & 432(406-460) & 352(284-438) & 235(205-269) \\ N & 48(42-57) & 102(97-109) & 90(85-97) & 118(114-123) \\ N_{\max } & 44 & 110 & 156 & 248 \\ N / N_{\max }[\%] & 109 & 93 & 58 & 48\end{array}$

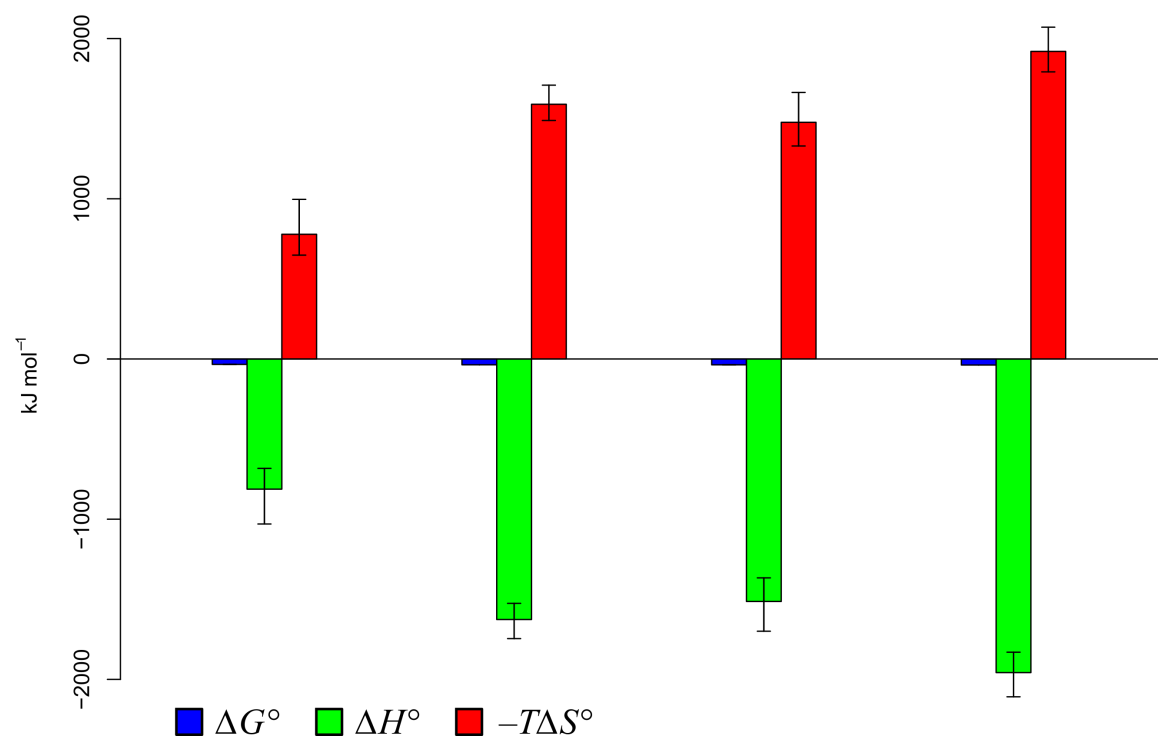

Figure 5. Thermodynamic fingerprints of the interaction of glycopolymers 1a-d with DC-SIGN ECD. The functional valency $N$ is the inverse of the fitting parameter $n$ determined in ITC experiments; $N_{\max }$ equals the total 
number of mannose epitopes on polymer. Thermodynamic data in numeric form can be found in the Supporting Information.

Similar to the binding affinity, the observed entropy-enthalpy compensation in the ITC experiments scales with the fitting parameter $n$ and thus with the functional valency $N(N=$ 1/n). Figure 6 depicts a plot of the thermodynamic profiles normalized by functional valency $N$ of the interaction. These fingerprints reflect the contribution of each interacting mannose residue of the multivalent glycoconjugates. For comparison, the thermodynamic profile of the monovalent ligand MeMan was included in the plot. Compared with the monovalent interaction, the multivalency effect enhances the normalized binding affinities of 1a-d by a factor of 54 to $113\left(K_{\mathrm{D}} \mathrm{MeMan} / K_{\mathrm{D}}\right.$ Man-PLL). The thermodynamic profile of MeMan reveals an enthalpy-driven interaction $\left(\Delta H_{n o r m}^{\circ}=-17.4 \mathrm{~kJ} \mathrm{~mol}^{-1}\right)$ that is partly compensated by an entropic penalty of $-T \Delta S_{\text {norm }}^{\circ}=3.1 \mathrm{~kJ} \mathrm{~mol}^{-1}$. Intriguingly, the normalized thermodynamic profiles for Man-PLL 1a-d are identical to each other within the error of the experiment. All glycopolymers display an enthalpically favorable interaction $\left(\Delta H_{\text {norm }}^{\circ} \approx-17 \mathrm{~kJ} \mathrm{~mol}^{-1}\right)$ with a similarly favorable entropic contribution $\left(-T \Delta S_{\text {norm }}^{\circ} \approx-9 \mathrm{~kJ} \mathrm{~mol}^{-1}\right)$. Thus, the observed affinity gain relative to MeMan is entirely related to a reduction of the entropic penalty for each carbohydrate epitope by $12 \mathrm{~kJ} \mathrm{~mol}^{-1}$ on average, whereas binding enthalpy essentially remains unchanged. Interestingly, this value is fairly close to the rigid body entropic barrier for fragment linking of $15-20 \mathrm{~kJ} \mathrm{~mol}^{-1}$ postulated by Murray and Verdonk. ${ }^{[52]}$ However, multivalent effects related to ligand entropy are likely superimposed by additional contributions from modification of polymer backbone flexibility upon binding. 


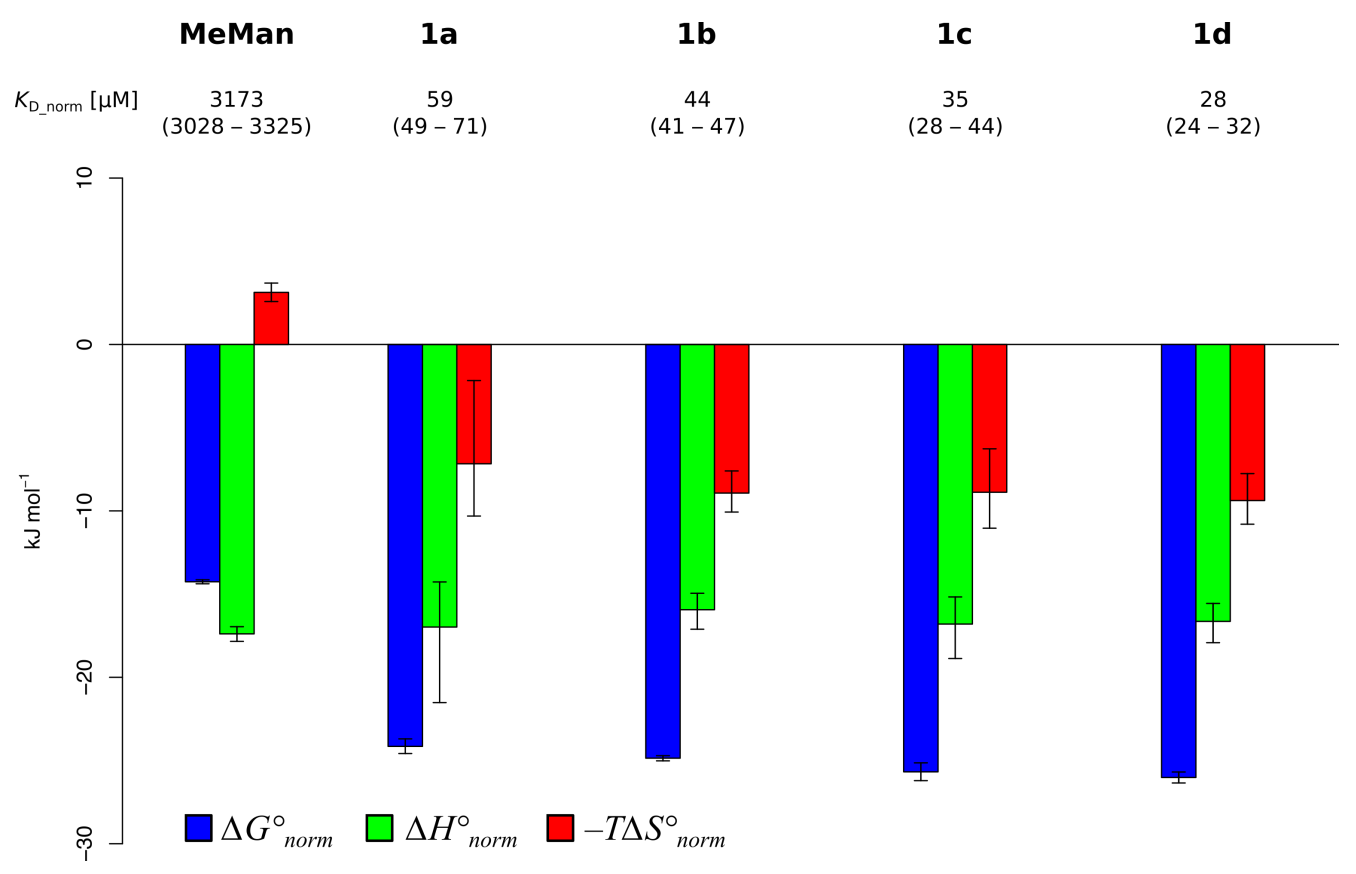

Figure 6. Normalized affinity and thermodynamic profile of MeMan and Man-PLL 1a-d $\left(\Delta G_{\text {norm }}^{\circ}=\right.$ $\left.\Delta G^{\circ} \times n ; \Delta H_{\text {norm }}^{\circ}=\Delta H^{\circ} \times n ;-T \Delta S_{\text {norm }}^{\circ}=-T \Delta S^{\circ} \times n ; K_{D_{-} \text {norm }}=e^{\frac{\Delta G_{\text {norm }}^{\circ}}{R T}}\right)$. Thermodynamic data in numeric form can be found in the Supporting Information.

The thermodynamics of multivalent ligands binding to lectins are often associated with an enhancement of binding entropy. ${ }^{[30,31,53]}$ The initial association of the ligand suffers from an entropic penalty due to its loss of translational and rotational degrees of freedom. In contrast to monovalent interactions, no additional entropy costs arise from the interaction of further epitopes of the multivalent construct. This effect can be equivalently described as a change of the ligand concentration in the unbound state from the standard concentration for the monovalent interaction to a higher effective concentration in multivalent systems. ${ }^{[54,55]}$ Thus, multivalent enhancement effects from statistical rebinding are essentially an entropic phenomenon, whereas the binding enthalpy of each individual interaction on a multivalent system resembles the monovalent interaction. This strongly suggests that the introduction of glycomimetic ligands with an improved enthalpic signature holds the potential to significantly 
increase binding affinity of glycopolymers. Hypothetically, even small gains in monovalent binding enthalpy will be significantly enhanced by the multivalency effect.

\section{Conclusions}

In this study, we demonstrate that Man-PLL glycopolymers 1a-d potently inhibit the attachment of viral envelope glycoproteins to DC-SIGN ${ }^{+}$cells. The presentation of mannose epitopes on the PLL scaffold resulted in a multivalent affinity enhancement of up to $10^{7}$. Intriguingly, the affinity of the polymers is strongly correlated with the size and shape of the molecular particles in solution. Large, elongated molecules (1b-d) were found to be more potent inhibitors of viral glycoprotein binding compared with the smaller, globular polymer 1a, probably because in elongated molecules the availability of epitopes for binding to a cell surface is spatially favored. Importantly, treatment of DC-SIGN ${ }^{+}$cells with Man-PLL 1d lead to a prolonged inhibition of SARS-CoV-2 spike S1 binding, highlighting the therapeutic potential of this approach.

A thermodynamic analysis of the Man-PLL/DC-SIGN interaction revealed that the multivalent affinity enhancement is mainly driven by an entropic advantage of $12 \mathrm{~kJ} \mathrm{~mol}^{-1}$, which is related to the reduction of translational and rigid body rotational entropy costs. At the same time, the enthalpic contribution of each interacting mannose on the polymer corresponds roughly to the value obtained for the monovalent interaction. This finding has important implications for the future design of glycopolymers and other multivalent glycomaterials. The presentation of glycomimetics with increased monovalent binding enthalpy on a multivalent support holds the potential to further improve potency and selectivity for lectin binding.

Efficient clearance of nanometer-sized polymeric therapeutics is a prerequisite for a prolonged pulmonary application without compound accumulation and associated toxicity. We demonstrated that fully bio-compatible Man-PLL polymers are efficiently internalized and 
degraded by their target cells and, thus, are unlikely to accumulate in lung tissue after inhalation.

With respect to the ongoing SARS-CoV-2 pandemic, DC-SIGN targeted Man-PLL polymers represent a novel treatment option for severe COVID-19, which is characterized by an exuberant immune response with the release of pro-inflammatory cytokines. Inhibition of the DC-SIGN-mediated infection of myeloid cells by pulmonary application of Man-PLL may be able to prevent progression of mild infections to severe forms of the disease.

\section{Experimental Part}

\section{Synthesis}

General methods: NMR spectra were recorded on a Bruker Avance III $500 \mathrm{MHz}$ spectrometer. Assignment of ${ }^{1} \mathrm{H}$ and ${ }^{13} \mathrm{C}$ NMR spectra was achieved using 2D methods (COSY, HSQC, $\mathrm{HMBC}$ ). Chemical shifts are expressed in ppm using residual $\mathrm{CHCl}_{3}, \mathrm{CHD}_{2} \mathrm{OD}$ or $\mathrm{HDO}$ as references. Electron spray ionization mass spectra (ESI-MS) were obtained on a Waters micromass ZQ Mass Spectrometer. Reactions were monitored by TLC using glass plates coated with silica gel $60 \mathrm{~F}_{254}$ (Merck, Darmstadt, Germany) and visualized by using UV light and/or by charring with a molybdate solution (a $0.02 \mathrm{M}$ solution of ammonium cerium sulfate dihydrate and ammonium molybdate tetrahydrate in aqueous $10 \% \mathrm{H}_{2} \mathrm{SO}_{4}$ ). MPLC separations were carried out on a CombiFlash Companion or $\mathrm{R}_{\mathrm{f}}$ from Teledyne Isco (Lincoln, NE, USA) equipped with RediSep flash columns. For purification of glycopolymers, Vivaspin ultrafiltration devices with a molecular weight cutoff of $6 \mathrm{kDa}$ or $50 \mathrm{kDa}$ (Sartorius, Göttingen, Germany) were used. Commercially available reagents and dry solvents were purchased from Sigma-Aldrich, Alfa Aesar and Acros Organics. Poly-L-lysine HBr polymers were acquired from PtS (Valencia, Spain). 
For the synthesis of the mannose building block 4, fluorescently labeled Man-PLL400 10, fluorescently labeled PLL $400 \mathbf{1 1}$ and the preparation of the chloroacetyleted poly-L-lysinse 3ac see Supporting Informations.

\section{General method for the synthesis of Man-PLL glycopolymers}

Chloroacetylated poly-L-lysine 3a-c (1 eq) was dissolved in DMF (0.3 mL) under an Argon atmosphere. To this 1,8-diazabicyclo[5.4.0]undec-7-en (DBU, 400 eq) and a solution of mannose derivative 4 in $30 \mu \mathrm{L} \mathrm{H}_{2} \mathrm{O}$ was added and the resulting mixture was shaken for 60 min at rt. Thioglycerol (1200 eq) and triethylamine (1200 eq) were added and shaking at rt was continued overnight. The mixture was poured into a vigorously stirred 1:1 mixture of EtOH and EtOAc (4 mL), which resulted in the precipitation of the polymer. After centrifugation (1000 $\mathrm{rpm}, 2 \mathrm{~min}, 4^{\circ} \mathrm{C}$ ), the supernatant was discarded and the precipitate was washed with $3 \mathrm{~mL}$ EtOH. The crude product was dissolved in $3 \mathrm{~mL} \mathrm{H}_{2} \mathrm{O}$ and purified by ultrafiltration using a Vivaspin centrifugal concentrator (Sartorius, Germany; $6 \mathrm{~mL}$, MWCO $6 \mathrm{kDa}$ or $50 \mathrm{kDa}$ ). Lyophilization gave the pure product as a colorless solid. Mannose loading was determined by NMR by comparing the integrals of thioglycerol $\mathrm{CH}_{2}-\mathrm{SR}$ and mannoside $\mathrm{CH}_{2}-\mathrm{SR} / \mathrm{CH}_{2}-\mathrm{CONH}$.

\section{Synthesis of Man-PLL 1a}

According to general method using chloroacetylated poly-L-lysine 3a (4.7 mg, $230 \mathrm{nmol}, 1 \mathrm{eq}$ ), DBU (14.0 mg, $92 \mu \mathrm{mol}, 400 \mathrm{eq})$, mannose derivative 4 (3.5 mg, $10 \mu \mathrm{mol}, 44 \mathrm{eq})$, thioglycerol (7.5 mg, $69 \mu \mathrm{mol}, 300 \mathrm{eq})$, and triethylamine $(7.0 \mathrm{mg}, 69 \mu \mathrm{mol}, 300 \mathrm{eq})$. The product $1 \mathrm{a}$ was obtained as a colorless solid (3.9 mg, $103 \mathrm{nmol}, 45 \%$ ). Mannose loading by NMR (see Supporting Information, Figure S1): 44\%.

Synthesis of Man-PLL $\mathbf{1 b}$ 
According to general method using chloroacetylated poly-L-lysine $\mathbf{3 b}(3.6 \mathrm{mg}, 70 \mathrm{nmol}, 1 \mathrm{eq})$, DBU (2.7 mg, $18 \mu \mathrm{mol}, 257 \mathrm{eq})$, mannose derivative 4 (2.7 mg, $9 \mu \mathrm{mol}, 127 \mathrm{eq})$, thioglycerol (5.7 mg, $53 \mu \mathrm{mol}, 757 \mathrm{eq}$ ), and triethylamine (5.4 mg, $53 \mu \mathrm{mol}, 757 \mathrm{eq})$. The product $\mathbf{1 b}$ was obtained as a colorless solid (4.3 mg, $45 \mathrm{nmol}, 64 \%$ ). Mannose loading by NMR (see Supporting Information, Figure S2): 46\%.

\section{Synthesis of Man-PLL $\mathbf{1 c}$}

According to general method using chloroacetylated poly-L-lysine $3 \mathbf{c}(5.7 \mathrm{mg}, 70 \mathrm{nmol}, 1 \mathrm{eq})$, DBU (4.3 mg, $28 \mu \mathrm{mol}, 400 \mathrm{eq})$, mannose derivative 4 (3.3 mg, $10 \mu \mathrm{mol}, 143 \mathrm{eq})$, thioglycerol (9.1 mg, $84 \mu \mathrm{mol}, 1200 \mathrm{eq})$, and triethylamine $(8.5 \mathrm{mg}, 84 \mu \mathrm{mol}, 1200 \mathrm{eq})$. The product $1 \mathrm{c}$ was obtained as a colorless solid (7.0 mg, $48 \mathrm{nmol}, 68 \%$ ). Mannose loading by NMR (see Supporting Information, Figure S3): 39\%.

\section{Synthesis of Man-PLL 1d}

According to general method using chloroacetylated poly-L-lysine $3 \mathbf{c}(4.2 \mathrm{mg}, 50 \mathrm{nmol}, 1 \mathrm{eq})$, DBU (3.0 mg, $20 \mu \mathrm{mol}, 400$ eq), mannose derivative 4 (3.1 mg, $9 \mu \mathrm{mol}, 180$ eq), thioglycerol (6.5 mg, $60 \mu \mathrm{mol}, 1200 \mathrm{eq})$, and triethylamine (6.1 mg, $60 \mu \mathrm{mol}, 1200 \mathrm{eq})$. The product $1 \mathrm{~d}$ was obtained as a colorless solid (4.3 mg, $26 \mathrm{nmol}, 51 \%$ ). Mannose loading by NMR (see Supporting Information, Figure S4): 62\%.

\section{Protein expression and purification}

E. coli BL21(DE3) cells were transfected with Novagen pET15b plasmids encoding for a recombinant DC-SIGN ECD linked to a thrombin cleavage site and an N-terminal His-Tag. Cells were initially cultivated overnight in $20 \mathrm{~mL}$ Luria Bertani medium substituted with 0.1 $\mathrm{mg} / \mathrm{mL}$ ampicillin at $37^{\circ} \mathrm{C}$ and then transferred into $1 \mathrm{~L}$ Terrific Broth medium substituted with $0.1 \mathrm{mg} / \mathrm{mL}$ ampicillin. Cells were incubated for $8 \mathrm{~h}$ at $37^{\circ} \mathrm{C}$ and DC-SIGN expression was 
induced by addition of $0.5 \mathrm{mM}$ IPTG. After $16 \mathrm{~h}$, cells were harvested by centrifugation $(4,000$ rpm, $\left.20 \mathrm{~min}, 4^{\circ} \mathrm{C}\right)$, resuspended in lysis buffer (50 mM Tris- $\mathrm{HCl}, 10 \mathrm{mM} \mathrm{MgCl}, 0.1 \%$ Triton X100), and lysed by sonication or addition of lysozyme and DNAse I. The cell lysate was centrifuged $\left(11000 \mathrm{rpm}, 20 \mathrm{~min}, 4{ }^{\circ} \mathrm{C}\right)$, the supernatant discarded, and the precipitated material was washed three times with washing buffer $(50 \mathrm{mM}$ Tris- $\mathrm{HCl}, \mathrm{pH}$ 8.0, $4 \mathrm{M}$ urea, $500 \mathrm{mM}$ $\mathrm{NaCl}, 1 \mathrm{mM}$ EDTA). The purified inclusion bodies were dissolved in $20 \mathrm{~mL}$ of denaturation buffer (6 M guanidine hydrochloride, $100 \mathrm{mM}$ Tris- $\mathrm{HCl}$, $\mathrm{pH} 8.0,1 \mathrm{mM} \mathrm{DTT}$ ) for $1 \mathrm{~h}$ at $37^{\circ} \mathrm{C}$. After ultracentrifugation $\left(22000 \mathrm{rpm}, 30 \mathrm{~min}, 4^{\circ} \mathrm{C}\right)$, the denatured protein was refolded by slow dilution into $100 \mathrm{~mL}$ refolding buffer (100 mM Tris- $\mathrm{HCl}, \mathrm{pH} 8.0,1 \mathrm{M}$ l-arginine, $150 \mathrm{mM}$ $\mathrm{NaCl}, 120 \mathrm{mM}$ sucrose). The mixture was stirred for $2 \mathrm{~d}$ at $4{ }^{\circ} \mathrm{C}$ and dialyzed against binding buffer (20 mM Tris- $\mathrm{HCl}, 500 \mathrm{mM} \mathrm{NaCl}, 25 \mathrm{mM} \mathrm{CaCl}_{2}, \mathrm{pH} 7.8$ ). Precipitated protein was removed by ultracentrifugation $\left(22000 \mathrm{rpm}, 30 \mathrm{~min}, 4^{\circ} \mathrm{C}\right)$ and the refolded soluble protein was purified by affinity chromatography on a mannose-sepharose column (elution buffer: $20 \mathrm{mM}$ TRIS, 500 mM NaCl, 2 mM EDTA, pH 7.8).

\section{Isothermal titration calorimetry}

A MicroCal ITC200 instrument (MicroCal, Northampton, USA) was used for all ITC experiments. All measurements were performed at $25^{\circ} \mathrm{C}$ using a reference power of $6 \mu \mathrm{cal} \mathrm{s}{ }^{-1}$, a stirring speed of $750 \mathrm{rpm}$, feedback mode high, and a filter period of $2 \mathrm{~s}$. Prior to the experiments, all protein samples were extensively dialyzed against ITC buffer (20 mM HEPES, $150 \mathrm{mM} \mathrm{NaCl}, 1 \mathrm{mM} \mathrm{CaCl}$, $\mathrm{pH}$ 7.4) and all non-protein samples were prepared using the dialysate buffer to minimize dilution effects. Protein concentration was determined photometrically with absorbance at $280 \mathrm{~nm}$ employing a calculated extinction coefficient of $70400 \mathrm{~mol}^{-1} \mathrm{~cm}^{-1}$. In a typical experiment, a glycoconjugate sample $(20-50 \mu \mathrm{M})$ was titrated into $50 \mu \mathrm{M}$ DC-SIGN ECD. The concentration of the glycoconjugate sample was chosen to ensure sufficient protein saturation $(>80 \%)$ at the end of the experiment. A control titration 
was performed for experiments with large observed dilution enthalpies and experimental data was corrected by subtraction of the blank values. In general, experimental data could be used directly without correction, in which case enthalpy of dilution was included as a separate fitting parameter. Baseline correction and integration was performed with NITPIC. ${ }^{[56,57]}$ Sedphat was used for nonlinear regression analysis of experimental data, determination of confidence intervals, and calculation of two-dimensional error surface projections. ${ }^{[57,58]}$

\section{Dynamic light scattering}

The size characteristics of Man-PLL 1a-d were analyzed by DLS with a Malvern Zetasizer Nano instrument (Malvern Panalytical, Malvern, UK). Samples containing $10 \mu \mathrm{M} 1 \mathrm{a}(0.38 \mathrm{mg}$ $\left.\mathrm{mL}^{-1}\right)$ or $2 \mu \mathrm{M} \mathbf{1 b}-\mathbf{d}\left(0.02-0.34 \mathrm{mg} \mathrm{mL}^{-1}\right)$ were allowed to equilibrate at $20{ }^{\circ} \mathrm{C}$ for two minutes prior to the experiments. Experiments were performed in triplicate and experimental data were analyzed with the manufacturer supplied software to obtain hydrodynamic radii (Z-average), polydispersity indices, and size distribution data.

\section{Analytical ultracentrifugation}

Sedimentation velocity experiments were performed for $410 \mu 1$ samples at concentrations of $0.8 \mathrm{mg} \mathrm{ml}^{-1}(22 \mu \mathrm{M})$ for Man-PLL 1a, $0.2 \mathrm{mg} \mathrm{ml}^{-1}(2 \mu \mathrm{M})$ for Man-PLL 1b, $1.3 \mathrm{mg} \mathrm{ml}^{-1}(9$ $\mu \mathrm{M})$ for Man-PLL 1c, and $0.2 \mathrm{mg} \mathrm{ml}^{-1}(1 \mu \mathrm{M})$ for Man-PLL 1d at $20{ }^{\circ} \mathrm{C}$ in $20 \mathrm{mM}$ HEPES, $150 \mathrm{mM} \mathrm{NaCl}, 1 \mathrm{mM} \mathrm{CaCl}$, $\mathrm{pH}$ 7.4. Centrifugation was performed at 42,000 $\mathrm{rpm}(128,000 \mathrm{x}$ g) using a Beckman XL-I Analytical Ultracentrifuge with an An-60 Ti rotor, and sedimentation was monitored using the interference optics with $12 \mathrm{~mm}$ double-sector charcoal-epon centerpieces. The data were analysed by fitting diffusion-deconvoluted differential sedimentation coefficient distributions (c(s) distributions) using the program SEDFIT, ${ }^{[59]}$ bestfit values of the frictional ratio $\left(f l f_{0}\right)$, meniscus and bottom positions, and time- and radiallyinvariant noise profiles were determined for each data set. Values of buffer density and viscosity 
were obtained from Sednterp. ${ }^{[60]}$ Values of partial specific volume were calculated for individual components of Man-PLLs 1a-d, namely lysine conjugated to mannose $\left(0.797 \mathrm{ml} \mathrm{g}^{-}\right.$ $\left.{ }^{1}\right)$ and for lysine conjugated to thioglycerol $\left(0.772 \mathrm{ml} \mathrm{g}^{-1}\right)$ using the method of Durchschlag and Zipper. ${ }^{[61]}$ Partial specific volumes were then calculated for different polymers according to estimated mass fraction of mannose or thioglycerol conjugated lysine in the polymer $(0.787 \mathrm{ml}$ $\mathrm{g}^{-1}$ for Man-PLL 1a, $0.787 \mathrm{ml} \mathrm{g}^{-1}$ for Man-PLL 1b, $0.786 \mathrm{ml} \mathrm{g}^{-1}$ for Man-PLL 1c, and $0.790 \mathrm{ml}$ $\mathrm{g}^{-1}$ for Man-PLL 1d. Signal-weighted average S values were calculated from c(s) distributions using the program GUSSI. ${ }^{[62]}$ Values of $D_{h}$ were calculated from diffusion coefficients, which in turn were calculated from signal-weighted average $S$ values and $f / f_{0}$ according to a standard scaling law. ${ }^{[63]}$

\section{Mammalian cell culture, flow cytometry, and fluorescence microscopy}

The following reagents were obtained through the NIH AIDS Reagent Program, Division of AIDS, NIAID, NIH: B-THP-1 DC-SIGN+ cells from Drs. Li Wu and Vineet N. KewalRamani (cat\# 9941), ${ }^{[64]}$ HIV-1 JR-CSF Fc-gp120 Recombinant Protein (Cat\#11556) from Aymeric de Parseval and Dr. John H. Elder. ${ }^{[65]}$ Recombinant ebola glycoprotein was obtained from R\&D Systems (cat\# 9016-EB-100), recombinant SARS-CoV-2 spike glycoprotein S1 subunit was purchased from Creative Biomart (cat\# Spike-191V).

Cells were maintained in RPMI 1640 medium substituted with $10 \% \mathrm{FCS}$ at $37{ }^{\circ} \mathrm{C}$. For IC50 measurements, 50000 cells were seeded in $50 \mu \mathrm{L}$ complete medium in a well of a 96-well plate. A serial dilution of the investigated ligand was prepared and mixed with an equal volume of Cy5-labeled glycoprotein. This mixture was added to the cell suspension to a final volume of $100 \mu \mathrm{L}$ and a final glycoprotein concentration of $10 \mathrm{nM}$ (gp120), $10 \mathrm{nM}$ (SARS-CoV-2 spike $\mathrm{S} 1)$, or $50 \mathrm{nM}(\mathrm{EBOV}-\mathrm{gp})$. After incubation for $30 \mathrm{~min}\left(37^{\circ} \mathrm{C}, 5 \% \mathrm{CO}_{2}\right)$, the cells were centrifuged (5 min, 100g) and washed with warm PBS. Data were collected on a Cytoflex flow cytometer (Beckman Coulter, Indianapolis, USA) and analyzed with FlowJo (FlowJo LLC). 
Mean fluorescence intensities were plotted and a nonlinear regression analysis employing a four parameter Hill model was performed with Prism 8 (Graphpad, San Diego, USA). For receptor blocking analysis, 50000 B-THP-1 DC-SIGN ${ }^{+}$cells were seeded and incubated with $100 \mathrm{nM} 1 \mathrm{~d}$ for $0 \mathrm{~min}$ to $6 \mathrm{~h}$, before washing and incubation with Cy5-labeled recombinant SARS-CoV-2 spike glycoprotein S1 subunit according to the protocol of the $\mathrm{IC}_{50}$ measurements. Additionally, B-THP-1 DC-SIGN ${ }^{+}$cells were incubated with $100 \mathrm{nM} 1 \mathrm{~d}$ for 30 min, washed, and incubated with Cy5-labeled recombinant SARS-CoV-2 spike glycoprotein $\mathrm{S} 1$ subunit after $0 \mathrm{~min}, 10 \mathrm{~min}, 30 \mathrm{~min}, 1 \mathrm{~h}, 3 \mathrm{~h}$, and $6 \mathrm{~h}$. Internalization experiments were performed with B-THP-1 DC-SIGN ${ }^{+}$cells and control B-THP-1 cells. 50000 cells were incubated with $100 \mathrm{nM} 10$ and $100 \mathrm{nM} 11$ for $30 \mathrm{~min}, 1 \mathrm{~h}, 3 \mathrm{~h}$, 6h, and 24h, washed with PBS, and analyzed by flow cytometry. For microscopic analysis cells were additionally incubated with $5 \mu \mathrm{g} / \mathrm{ml}$ CellMask Deep Red Plasma membrane stain (C10046, Invitrogen, Thermo Fisher Scientific, Switzerland) for $10 \mathrm{~min}$. Images were recorded with the Leica SP8 confocal point scanning microscope using a HC PL Apo CS 40x (NA 1.1) objective (Leica Microsystems, Germany). Comparisons between the conditions were performed using one-way ANOVA with Dunnett's multiple comparison posttest with a 0.05 confidence level accepted for statistical significance $(* \mathrm{P} \leq 0.05, * * \mathrm{P} \leq 0.01, * * * \mathrm{P} \leq 0.001, * * * * \mathrm{P} \leq 0.0001)$.

\section{Supporting Information}

Electronic Supporting Information is available free of charge on the ACS website. Synthesis of polymer precursors, NMR characterization of $\mathbf{1 a - d}$, additional information on ITC titrations, calculation of equilibrium concentrations, thermodynamic data, thermograms, sedimentation velocity data from AUC.

\section{References}

(1) Monteiro, J.; Lepenies, B. Myeloid C-Type Lectin Receptors in Viral Recognition and Antiviral Immunity. Viruses 2017, 9 (3), 59. 
(2) Bermejo-Jambrina, M.; Eder, J.; Helgers, L. C.; Hertoghs, N.; Nijmeijer, B. M.; Stunnenberg, M.; Geijtenbeek, T. B. H. C-Type Lectin Receptors in Antiviral Immunity and Viral Escape. Front. Immunol. 2018, 9 (MAR), 590.

(3) Garcia-Vallejo, J. J.; van Kooyk, Y. DC-SIGN: The Strange Case of Dr. Jekyll and Mr. Hyde. Immunity 2015, 42 (6), 983-985.

(4) van Kooyk, Y.; Geijtenbeek, T. B. H. DC-SIGN: Escape Mechanism for Pathogens. Nat. Rev. Immunol. 2003, 3 (9), 697-709.

(5) Martín-Moreno, A.; Muñoz-Fernández, M. A. Dendritic Cells, the Double Agent in the War Against HIV-1. Front. Immunol. 2019, 10 (OCT), 2485.

(6) Marzi, A.; Möller, P.; Hanna, S. L.; Harrer, T.; Eisemann, J.; Steinkasserer, A.; Becker, S.; Baribaud, F.; Pöhlmann, S. Analysis of the Interaction of Ebola Virus Glycoprotein with DC-SIGN (Dendritic Cell-Specific Intercellular Adhesion Molecule 3-Grabbing Nonintegrin) and Its Homologue DC-SIGNR. J. Infect. Dis. 2007, 196 (s2), S237-S246.

(7) Simmons, G.; Reeves, J. D.; Grogan, C. C.; Vandenberghe, L. H.; Baribaud, F.; Whitbeck, J. C.; Burke, E.; Buchmeier, M. J.; Soilleux, E. J.; Riley, J. L.; et al. DC-SIGN and DC-SIGNR Bind Ebola Glycoproteins and Enhance Infection of Macrophages and Endothelial Cells. Virology 2003, 305 (1), 115-123.

(8) Hillaire, M. L. B.; Nieuwkoop, N. J.; Boon, A. C. M.; de Mutsert, G.; Vogelzang-van Trierum, S. E.; Fouchier, R. A. M.; Osterhaus, A. D. M. E.; Rimmelzwaan, G. F. Binding of DC-SIGN to the Hemagglutinin of Influenza A Viruses Supports Virus Replication in DC-SIGN Expressing Cells. PLoS One 2013, 8 (2), e56164.

(9) Pöhlmann, S.; Zhang, J.; Baribaud, F.; Chen, Z.; Leslie, G. J.; Lin, G.; Granelli-Piperno, A.; Doms, R. W.; Rice, C. M.; McKeating, J. A. Hepatitis C Virus Glycoproteins Interact with DC-SIGN and DC-SIGNR. J. Virol. 2003, 77 (7), 4070-4080.

(10) Marzi, A.; Gramberg, T.; Simmons, G.; Moller, P.; Rennekamp, A. J.; Krumbiegel, M.; Geier, M.; Eisemann, J.; Turza, N.; Saunier, B.; et al. DC-SIGN and DC-SIGNR Interact with the Glycoprotein of Marburg Virus and the S Protein of Severe Acute Respiratory Syndrome Coronavirus. J. Virol. 2004, 78 (21), 12090-12095.

(11) Routhu, N. K.; Lehoux, S. D.; Rouse, E. A.; Bidokhti, M. R. M.; Giron, L. B.; Anzurez, A.; Reid, S. P.; Abdel-Mohsen, M.; Cummings, R. D.; Byrareddy, S. N. Glycosylation of Zika Virus Is Important in Host-Virus Interaction and Pathogenic Potential. Int. J. Mol. Sci. 2019, 20 (20), 5206.

(12) Tassaneetrithep, B.; Burgess, T. H.; Granelli-Piperno, A.; Trumpfheller, C.; Finke, J.; Sun, W.; Eller, M. A.; Pattanapanyasat, K.; Sarasombath, S.; Birx, D. L.; et al. DC-SIGN 
(CD209) Mediates Dengue Virus Infection of Human Dendritic Cells. J. Exp. Med. 2003, 197 (7), 823-829.

(13) Yang, Z.-Y.; Huang, Y.; Ganesh, L.; Leung, K.; Kong, W.-P.; Schwartz, O.; Subbarao, K.; Nabel, G. J. PH-Dependent Entry of Severe Acute Respiratory Syndrome Coronavirus Is Mediated by the Spike Glycoprotein and Enhanced by Dendritic Cell Transfer through DC-SIGN. J. Virol. 2004, 78 (11), 5642-5650.

(14) Colmenares, M.; Puig-Kröger, A.; Pello, O. M.; Corbí, A. L.; Rivas, L. Dendritic Cell (DC)-Specific Intercellular Adhesion Molecule 3 (ICAM-3)-Grabbing Nonintegrin (DCSIGN, CD209), a C-Type Surface Lectin in Human DCs, Is a Receptor for Leishmania Amastigotes. J. Biol. Chem. 2002, 277 (39), 36766-36769.

(15) Brufsky, A.; Lotze, M. T. DC/L-SIGNs of Hope in the COVID-19 Pandemic. J. Med. Virol. 2020, jmv.25980.

(16) Watanabe, Y.; Allen, J. D.; Wrapp, D.; McLellan, J. S.; Crispin, M. Site-Specific Glycan Analysis of the SARS-CoV-2 Spike. Science (80-. ). 2020, eabb9983.

(17) Gao, C.; Zeng, J.; Jia, N.; Stavenhagen, K.; Matsumoto, Y.; Zhang, H.; Li, J.; Hume, A. J.; Muehlberger, E.; van Die, I.; et al. SARS-CoV-2 Spike Protein Interacts with Multiple Innate Immune Receptors. bioRxiv 2020, 2020.07.29.227462.

(18) Amraie, R.; Napoleon, M. A.; Yin, W.; Berrigan, J.; Suder, E.; Zhao, G.; Olejnik, J.; Gummuluru, S.; Muhlberger, E.; Chitalia, V.; et al. CD209L/L-SIGN and CD209/DCSIGN Act as Receptors for SARS-CoV-2 and Are Differentially Expressed in Lung and Kidney Epithelial and Endothelial Cells. Biorxiv 2020, 2020.06.22.165803.

(19) Amraei, R.; Rahimi, N. COVID-19, Renin-Angiotensin System and Endothelial Dysfunction. Cells 2020, 9 (7), 1652.

(20) Ordanini, S.; Varga, N.; Porkolab, V.; Thépaut, M.; Belvisi, L.; Bertaglia, A.; Palmioli, A.; Berzi, A.; Trabattoni, D.; Clerici, M.; et al. Designing Nanomolar Antagonists of DC-SIGN-Mediated HIV Infection: Ligand Presentation Using Molecular Rods. Chem. Commun. 2015, 51 (18), 3816-3819.

(21) Chiodo, F. Temp-Ref-Novel ACE2-Independent Carbohydrate-Binding of SARS-CoV2 Spike Protein to Host Lectins and Lung Microbiota.

(22) Thepaut, M.; Luczkowiak, J.; Vives, C.; Labiod, N.; Bally, I.; Lasala, F.; Grimoire, Y.; Fenel, D.; Sattin, S.; Thielens, N.; et al. DC/L-SIGN Recognition of Spike Glycoprotein Promotes SARS-CoV-2 Trans-Infection and Can Be Inhibited by a Glycomimetic Antagonist. Biorxiv 2020, 2020.08.09.242917.

(23) Katz, D. H.; Tahir, U. A.; Ngo, D.; Benson, M. D.; Bick, A. G.; Pampana, A.; Gao, Y.; 
Keyes, M. J.; Correa, A.; Sinha, S.; et al. Proteomic Profiling in Biracial Cohorts Implicates DC-SIGN as a Mediator of Genetic Risk in COVID-19. Medrxiv 2020, 2020.06.09.20125690.

(24) Mazzon, M.; Marsh, M. Targeting Viral Entry as a Strategy for Broad-Spectrum Antivirals. F1000Research 2019, 8, 1628.

(25) Zakaria, M. K.; Carletti, T.; Marcello, A. Cellular Targets for the Treatment of Flavivirus Infections. Front. Cell. Infect. Microbiol. 2018, 8.

(26) Krishnan, M.; Garcia-Blanco, M. Targeting Host Factors to Treat West Nile and Dengue Viral Infections. Viruses 2014, 6 (2), 683-708.

(27) Rodríguez-Pérez, L.; Ramos-Soriano, J.; Pérez-Sánchez, A.; Illescas, B. M.; Muñoz, A.; Luczkowiak, J.; Lasala, F.; Rojo, J.; Delgado, R.; Martín, N. Nanocarbon-Based Glycoconjugates as Multivalent Inhibitors of Ebola Virus Infection. J. Am. Chem. Soc. 2018, 140 (31), 9891-9898.

(28) Ramos-Soriano, J.; Reina, J. J.; Illescas, B. M.; De La Cruz, N.; Rodríguez-Pérez, L.; Lasala, F.; Rojo, J.; Delgado, R.; Martín, N. Synthesis of Highly Efficient Multivalent Disaccharide/[60]Fullerene Nanoballs for Emergent Viruses. J. Am. Chem. Soc. 2019, 141 (38), 15403-15412.

(29) Schwegmann, A.; Brombacher, F. Host-Directed Drug Targeting of Factors Hijacked by Pathogens. Sci. Signal. 2008, 1 (29), re8-re8.

(30) Dam, T. K.; Brewer, C. F. Multivalent Lectin-Carbohydrate Interactions. In Advances in carbohydrate chemistry and biochemistry; 2010; Vol. 63, pp 139-164.

(31) Dam, T. K.; Gerken, T. A.; Cavada, B. S.; Nascimento, K. S.; Moura, T. R.; Brewer, C. F. Binding Studies of $\alpha$-GalNAc-Specific Lectins to the $\alpha$-GalNAc (Tn-Antigen) Form of Porcine Submaxillary Mucin and Its Smaller Fragments. J. Biol. Chem. 2007, 282 (38), 28256-28263.

(32) Dam, T. K.; Brewer, C. F. Effects of Clustered Epitopes in Multivalent Ligand-Receptor Interactions. Biochemistry 2008, 47 (33), 8470-8476.

(33) Lee, R. T.; Lee, Y. C. Affinity Enhancement by Multivalent Lectin-Carbohydrate Interaction. Glycoconjugate Journal. Springer 2000, pp 543-551.

(34) Becer, C. R.; Gibson, M. I.; Geng, J.; Ilyas, R.; Wallis, R.; Mitchell, D. A.; Haddleton, D. M. High-Affinity Glycopolymer Binding to Human DC-SIGN and Disruption of DCSIGN Interactions with HIV Envelope Glycoprotein. J. Am. Chem. Soc. 2010, 132 (43), $15130-15132$.

(35) Ng, S.; Bennett, N. J.; Schulze, J.; Gao, N.; Rademacher, C.; Derda, R. Genetically- 
Encoded Fragment-Based Discovery of Glycopeptide Ligands for DC-SIGN. Bioorg. Med. Chem. 2018.

(36) Wang, S.-K.; Liang, P.-H.; Astronomo, R. D.; Hsu, T.-L.; Hsieh, S.-L.; Burton, D. R.; Wong, C.-H. Targeting the Carbohydrates on HIV-1: Interaction of Oligomannose Dendrons with Human Monoclonal Antibody 2G12 and DC-SIGN. Proc. Natl. Acad. Sci. U. S. A. 2008, 105 (10), 3690-3695.

(37) Martínez-Ávila, O.; Bedoya, L. M.; Marradi, M.; Clavel, C.; Alcamí, J.; Penadés, S. Multivalent Manno-Glyconanoparticles Inhibit DC-SIGN-Mediated HIV-1 TransInfection of Human T Cells. ChemBioChem 2009, 10 (11), 1806-1809.

(38) Taouai, M.; Porkolab, V.; Chakroun, K.; Cheneau, C.; Luczkowiak, J.; Abidi, R.; Lesur, D.; Cragg, P. J.; Halary, F.; Delgado, R.; et al. Unprecedented Thiacalixarene Fucoclusters as Strong Inhibitors of Ebola Cis-Cell Infection and HCMV-GB Glycoprotein/DC-SIGN C-Type Lectin Interaction. Bioconjug. Chem. 2019, 30 (4), 1114-1126.

(39) Owen, K. Regulatory Toxicology Considerations for the Development of Inhaled Pharmaceuticals. Drug Chem. Toxicol. 2013, 36 (1), 109-118.

(40) Lim, Y. H.; Tiemann, K. M.; Hunstad, D. A.; Elsabahy, M.; Wooley, K. L. Polymeric Nanoparticles in Development for Treatment of Pulmonary Infectious Diseases. Wiley Interdiscip. Rev. Nanomedicine Nanobiotechnology 2016, 8 (6), 842-871.

(41) Rai, R.; Alwani, S.; Badea, I. Polymeric Nanoparticles in Gene Therapy: New Avenues of Design and Optimization for Delivery Applications. Polymers (Basel). 2019, 11 (4), 745 .

(42) Herrendorff, R.; Hänggi, P.; Pfister, H.; Yang, F.; Demeestere, D.; Hunziker, F.; Frey, S.; Schaeren-Wiemers, N.; Steck, A. J.; Ernst, B. Selective in Vivo Removal of Pathogenic Anti-MAG Autoantibodies, an Antigen-Specific Treatment Option for AntiMAG Neuropathy. Proc. Natl. Acad. Sci. 2017, 114 (18), E3689-E3698.

(43) Aliu, B.; Demeestere, D.; Seydoux, E.; Boucraut, J.; Delmont, E.; Brodovitch, A.; Oberholzer, T.; Attarian, S.; Théaudin, M.; Tsouni, P.; et al. Selective Inhibition of AntiMAG IgM Autoantibody Binding to Myelin by an Antigen-Specific Glycopolymer. $J$. Neurochem. 2020.

(44) Hoppe, C. A.; Lee, Y. C. Accumulation of a Nondegradable Mannose Ligand within Rabbit Alveolar Macrophages. Receptor Reutihzation Is Independent of Ligand Degradation. Biochemistry 1984, 23 (8), 1723-1730.

(45) Thoma, G.; Patton, J. T.; Magnani, J. L.; Ernst, B.; Öhrlein, R.; Duthaler, R. O. Versatile 
Functionalization of Polylysine: Synthesis, Characterization, and Use of Neoglycoconjugates. J. Am. Chem. Soc. 1999, 121 (25), 5919-5929.

(46) Watanabe, Y.; Bowden, T. A.; Wilson, I. A.; Crispin, M. Exploitation of Glycosylation in Enveloped Virus Pathobiology. Biochim. Biophys. Acta - Gen. Subj. 2019, 1863 (10), $1480-1497$.

(47) Fehres, C. M.; Kalay, H.; Bruijns, S. C. M.; Musaafir, S. A. M.; Ambrosini, M.; Van Bloois, L.; Van Vliet, S. J.; Storm, G.; Garcia-Vallejo, J. J.; Van Kooyk, Y. CrossPresentation through Langerin and DC-SIGN Targeting Requires Different Formulations of Glycan-Modified Antigens. J. Control. Release 2015, 203, 67-76.

(48) Cairo, C. W.; Gestwicki, J. E.; Kanai, M.; Kiessling, L. L. Control of Multivalent Interactions by Binding Epitope Density. J. Am. Chem. Soc. 2002, 124 (8), 1615-1619.

(49) Gestwicki, J. E.; Cairo, C. W.; Strong, L. E.; Oetjen, K. A.; Kiessling, L. L. Influencing Receptor-Ligand Binding Mechanisms with Multivalent Ligand Architecture. J. Am. Chem. Soc. 2002, 124 (50), 14922-14933.

(50) Ting, S. R. S.; Chen, G.; Stenzel, M. H. Synthesis of Glycopolymers and Their Multivalent Recognitions with Lectins. Polym. Chem. 2010, 1 (9), 1392.

(51) Igde, S.; Röblitz, S.; Müller, A.; Kolbe, K.; Boden, S.; Fessele, C.; Lindhorst, T. K.; Weber, M.; Hartmann, L. Linear Precision Glycomacromolecules with Varying Interligand Spacing and Linker Functionalities Binding to Concanavalin A and the Bacterial Lectin FimH. Macromol. Biosci. 2017, 17 (12), 1700198.

(52) Murray, C. W.; Verdonk, M. L. Entropic Consequences of Linking Ligands. In Fragment-based Approaches in Drug Discovery; Wiley Blackwell, 2006; Vol. 34, pp $55-66$.

(53) Dam, T. K.; Brewer, C. F. Thermodynamic Studies of Lectin-Carbohydrate Interactions by Isothermal Titration Calorimetry. Chem. Rev. 2002, 102 (2), 387-429.

(54) Jencks, W. P. On the Attribution and Additivity of Binding Energies. Proc. Natl. Acad. Sci. U. S. A. 1981, 78 (7 I), 4046-4050.

(55) Zhou, H. X.; Gilson, M. K. Theory of Free Energy and Entropy in Noncovalent Binding. Chem. Rev. 2009, 109 (9), 4092-4107.

(56) Scheuermann, T. H.; Brautigam, C. A. High-Precision, Automated Integration of Multiple Isothermal Titration Calorimetric Thermograms: New Features of NITPIC. Methods 2015, 76, 87-98.

(57) Brautigam, C. A.; Zhao, H.; Vargas, C.; Keller, S.; Schuck, P. Integration and Global Analysis of Isothermal Titration Calorimetry Data for Studying Macromolecular 
Interactions. Nat. Protoc. 2016, 11 (5), 882-894.

(58) Piszczek, G. SEDPHAT - A Platform for Global ITC Analysis and Global Multi-Method Analysis of Molecular Interactions. Methods 2015, 76, 137-148.

(59) Schuck, P. Size-Distribution Analysis of Macromolecules by Sedimentation Velocity Ultracentrifugation and Lamm Equation Modeling. Biophys. J. 2000, 78 (3), 1606-1619.

(60) Laue, T. M.; Shah, B. D.; Ridgeway, T. M.; Pelletier, S. L. Computer- Aided Interpretation of Analytical Sedimentation Data for Proteins; Harding, S. E., Rowe, A. J., Horton, J. C., Eds.; The Royal Society of Chemistry: Cambridge, United Kingdom, 1992.

(61) Durchschlag, H.; Zipper, P. Calculation of the Partial Volume of Organic Compounds and Polymers. In Progress in Colloid \& Polymer Science; Springer-Verlag GmbH \& Company KG, 1994; Vol. 94, pp 20-39.

(62) Brautigam, C. A. Calculations and Publication-Quality Illustrations for Analytical Ultracentrifugation Data. Methods Enzymol. 2015, 562, 109-133.

(63) Brown, P. H.; Balbo, A.; Schuck, P. Characterizing Protein-Protein Interactions by Sedimentation Velocity Analytical Ultracentrifugation. Curr. Protoc. Immunol. 2008, 81 (1), Unit 18.15.

(64) Wu, L.; Martin, T. D.; Carrington, M.; KewalRamani, V. N. Raji B Cells, Misidentified as THP-1 Cells, Stimulate DC-SIGN-Mediated HIV Transmission. Virology 2004, 318 (1), 17-23.

(65) Binley, J. M.; Ngo-Abdalla, S.; Moore, P.; Bobardt, M.; Chatterji, U.; Gallay, P.; Burton, D. R.; Wilson, I. A.; Elder, J. H.; de Parseval, A. Inhibition of HIV Env Binding to Cellular Receptors by Monoclonal Antibody 2G12 as Probed by Fc-Tagged Gp120. Retrovirology 2006, 3, 39. 